\title{
Phytoplasmas Associated with Elm Yellows: Molecular Variability and Differentiation from Related Organisms
}

H. M. Griffiths and W. A. Sinclair, Department of Plant Pathology, Cornell University, Ithaca, NY 14853-4203; E. Boudon-Padieu and X. Daire, Institut National de Recherche Agronomique, Station de Recherches sur les Phytoplasmes, BV 1540, 21034 Dijon Cedex, France; I.-M. Lee, USDA-ARS, Molecular Plant Pathology Laboratory, Beltsville, MD 20705; A. Sfalanga, Istituto di Patologia e Zoologia Forestale ed Agraria, University of Firenze, 50100 Firenze, Italy; and A. Bertaccini, Istituto di Patologia Vegetale, Universita degli Studi di Bologna, 40126 Bologna, Italy

\begin{abstract}
Griffiths, H. M., Sinclair, W. A., Boudon-Padieu, E., Daire, X., Lee, I.-M., Sfalanga, A., and Bertaccini, A. 1999. Phytoplasmas associated with elm yellows: Molecular variability and differentiation from related organisms. Plant Dis. 83:1101-1104.

Restriction fragment length polymorphism (RFLP) analyses were performed on polymerase chain reaction (PCR) amplimers of phytoplasmal DNA from eight samples obtained from Ulmus spp. (elms) affected by elm yellows (EY) in Italy and the United States, from Catharanthus roseus infected with strain EY1, and from five other plant species infected with phytoplasmas of the EY group sensu lato (group 16SrV). RFLP profiles obtained with restriction enzyme TaqI from ribosomal DNA amplified with primer pair P1/P7 differentiated elm-associated phytoplasmas from strains originally detected in Apocynum cannabinum, Prunus spp., Rubus fruticosus, Vitis vinifera, and Ziziphus jujuba. RFLP profiles obtained similarly with BfaI differentiated strains from A. cannabinum and $V$. vinifera from other phytoplasmas of group 16SrV. Elm-associated strains from within the United States had two RFLP patterns in ribosomal DNA based on presence or absence of an RsaI site in the 16S-23S spacer. Elmassociated phytoplasma strains from Italy were distinguished from those of American origin by RFLPs obtained with MseI in the same fragment of non-ribosomal DNA. Strain HD1, which was discovered in A. cannabinum associated with EY-diseased elms in New York State, was unique among the strains studied.
\end{abstract}

The phytoplasmal disease elm yellows (EY) occurs in North America and Europe $(8,15-17,23)$. EY causes decline of Eurasian elm species and hybrids in some European localities, notably in Italy $(8,9,15)$. Numerous phytoplasma strains in elms in Europe have been identified, and the predominant strain in each case has been a member of the EY group sensu lato (= group $16 \mathrm{SrV} ; 8-11,16)$. Strain ULW from a witches'-broom on Ulmus minor (European field elm) in France was the first to be identified $(18,22)$.

Significant EY outbreaks occur sporadically in indigenous elms ( $U$. americana L., U. rubra Mühl., U. alata Michx., U. serotina Sarg., and $U$. crassifolia Nutt.) in the United States and are lethal in these species (23). However, elms of Eurasian origin growing in North America have

Corresponding author: H. M. Griffiths

E-mail: hmg1@cornell.edu

This research was supported by the USDA McIntire-Stennis Cooperative Forestry Program.

Accepted for publication 25 August 1999.

Publication no. D-1999-1004-02R

(C) 1999 The American Phytopathological Society rarely been damaged by EY. The reason for this escape is unknown. Understanding more about the relatedness of elm-inhabiting EY strains is important for determining host and epidemiological differences in EY between Europe and North America.

Phytoplasmas of the EY group sensu lato occur in diverse plant genera including, among others, Apocynum, Prunus, Rubus, Vitis, and Ziziphus in addition to Ulmus $(1,6,7,10,12,14,16,22)$. In New York State, A. cannabinum (hemp dogbane) infected with a phytoplasma of group $16 \mathrm{SrV}$ was found growing on the site of an EY outbreak. This isolate was transferred to periwinkle and designated HD1 (6).

The aim of this study was to address the following two hypotheses: first, that phytoplasma strains of group $16 \mathrm{SrV}$ inhabiting Ulmus spp. in North America and Europe comprise a genetically coherent subgroup and, second, that HD1 differs from elminhabiting phytoplasmas. Abstracts describing part of this work have appeared $(6,7)$.

\section{MATERIALS AND METHODS}

Phytoplasma collection and propagation. Nine samples of phytoplasma-infected Ulmus spp. representing $U$. americana, U. rubra, U. minor (U. carpinifolia),
U. chenmoui, and the hybrid clone 'Lobel' plus a sample from A. cannabinum were obtained from naturally infected plants in Italy and the United States (Table 1). Phytoplasmal infection was initially indicated by symptoms and, in A. cannabinum, by means of the DAPI (4', 6-diamidino-2phenylindole $2 \mathrm{HCl}$ ) fluorescence test $(21,24)$. Five DNA samples previously collected from plants of other species infected with phytoplasmas of group $16 \mathrm{SrV}$ were used as standards (Table 1). Eight samples of diseased elm were utilized directly for DNA extraction. Phytoplasmas from the other two source plants (EY1 from elm and HD1 from hemp dogbane) were transmitted by Cuscuta subinclusa (dodder) to Catharanthus roseus (periwinkle) grown from seed and then were maintained in this species by serial grafting. Plants were grown in a screened greenhouse with periodic insecticide treatments to prevent unwanted introduction or transmission of phytoplasmas.

DNA extraction and amplification. The nucleic acid extraction procedure of Lee et al. (9) was used for elm samples, and the method of Dellaporta et al. (3) was used for periwinkle samples, beginning with the grinding of $0.75 \mathrm{~g}$ of fresh leaf midribs in liquid nitrogen. The final pellets were treated with RNase, and DNA concentrations were estimated spectrophotometrically using standard techniques (19).

Phytoplasmal DNA was amplified in polymerase chain reactions (PCRs) in which two primer pairs, $\mathrm{P} 1 / \mathrm{P} 7$ and FD9f/r, were used routinely. P1/P7 $(4,20)$ amplifies nearly the entire $16 \mathrm{~S}$ rRNA gene, the $16 \mathrm{~S}$ $23 \mathrm{~S}$ spacer, and a small portion of the $23 \mathrm{~S}$ rRNA gene (1.8-kilobase [kb] product). Primer pair FD9f/r (2) amplifies a 1.3-kb fragment of non-ribosomal DNA. A third primer pair, P4/P7 (523-base pair [bp] product; 20) was used with elm samples from Bismarck and Fargo, North Dakota, because DNA amplified from these samples with primer set $\mathrm{P} 1 / \mathrm{P} 7$ was insufficient for restriction fragment length polymorphism (RFLP) analyses.

Amplifications with ribosomal and nonribosomal primers were performed in $50-\mu \mathrm{l}$ mixtures containing $100 \mathrm{ng}$ of nucleic acid 
and $1.25 \mathrm{U}$ of Taq DNA polymerase (GIBCO BRL, Gaithersburg, MD) as described by Lee et al. (11) and Daire et al. (2). Parameters used for 35-cycle PCRs with primer pair $\mathrm{P} 1 / \mathrm{P} 7$ were denaturation at $94^{\circ} \mathrm{C}$ for $30 \mathrm{~s}(90 \mathrm{~s}$ for the first cycle), annealing for $55 \mathrm{~s}$ at $55^{\circ} \mathrm{C}$, and primer extension for $80 \mathrm{~s}$ ( $9 \mathrm{~min}$ for last cycle) at $72^{\circ} \mathrm{C}$. Parameters used with primer pair $\mathrm{P} 4 / \mathrm{P} 7$ for 35-cycle PCR were as previously described (20). Parameters used with primer pair FD9f/r for 40-cycle PCRs were denaturation at $92^{\circ} \mathrm{C}$ for $30 \mathrm{~s}(90 \mathrm{~s}$ for the first cycle), annealing for $30 \mathrm{~s}$ at $54^{\circ} \mathrm{C}$, and primer extension for $80 \mathrm{~s}$ at $72^{\circ} \mathrm{C}$. PCR products in 5- $\mu \mathrm{l}$ samples of reaction mixtures were detected and their sizes estimated by electrophoresis with size standards in $0.7 \%$ agarose gel in Tris-borate EDTA (TBE) buffer, followed by staining with ethidium bromide and visualizing the DNA bands with a UV transilluminator.

RFLP analyses. Aliquots of PCR products obtained with primer pair P1/P7 were digested overnight at $37^{\circ} \mathrm{C}$ with either AluI, BamHI, HaeIII, HhaI, HpaII, MseI, RsaI, ThaI (GIBCO BRL), or BfaI (New England Biolabs, Beverly, MA) or at $65^{\circ} \mathrm{C}$ overnight with TaqI (GIBCO BRL). PCR products obtained with primer pair $\mathrm{P} 4 / \mathrm{P} 7$ were digested overnight at $37^{\circ} \mathrm{C}$ with $R s a \mathrm{I}$ or at $65^{\circ} \mathrm{C}$ overnight with TaqI. Each digest used $10 \mathrm{U}$ of enzyme in the presence of spermidine $(40 \mathrm{mM})$ in a $10-\mu$ l reaction, except that $5 \mathrm{U}$ of enzyme was used with MseI, ThaI, and BfaI. Restriction digest products were separated by electrophoresis in $5,6.5$, or $9 \%$ acrylamide gels (concentration depending upon molecular weight of the expected bands) prepared in TBE (19) and were stained with ethidium bromide. DNA bands were visualized as described above. FD9f/r PCR products were digested overnight at $37^{\circ} \mathrm{C}$ with $5 \mathrm{U}$ of $\mathrm{Mse} \mathrm{I}$ in a $10-\mu \mathrm{l}$ reaction. The entire restriction digest was separated by electrophoresis in a $10 \%$ acrylamide gel prepared in TBE (19) and stained and visualized as described above.

Nucleotide sequencing and sequence alignment. The P1/P7 amplimers from strains EY1, EY-WV, and HD1 were sequenced, because these strains represented the three RFLP profiles encountered in rDNA of group $16 \mathrm{SrV}$ phytoplasmas from North America. The PCR products were purified using $0.7 \%$ low-melting-point agarose (Ultrapure LMP, GIBCO BRL) prepared in Tris-acetate EDTA (TAE) and extracted with the QiAquick gel extraction kit (Qiagen, Chatsworth, CA). The final elution from the column was performed with sterile distilled water. DNA concentrations were estimated spectrophotometrically and adjusted for sequencing using sterile distilled water. Sequencing was performed by automated equipment in Cornell University's Biotechnology Center. Each strand was sequenced in both directions with at least five primers located along the template to allow overlapping of sequences and thus eliminate ambiguous regions. Sequence data were collated, aligned with the aster yellows sequence of Lim and Sears (13), and mapped using LASERGENE software (5). Locations of restriction enzyme recognition sites reported here are based on the aster yellows sequence.

Nucleotide sequence accession numbers. Sequences of the P1/P7 amplimers of phytoplasma strains EY1, EY-WV, and HD1 were deposited in GenBank with accession numbers AF 122910, AF 122911, and AF 122912, respectively.

\section{RESULTS}

P1/P7 amplimers and RFLPs. Profiles from strains EY1, EY-NYII, and ITEY were identical with 10 enzymes (Table 2). Restriction sites in the P1/P7 amplimer of strain EY-WV, identified from sequence

Table 1. Phytoplasma strain, geographic origin, host origin, and source

\begin{tabular}{|c|c|c|c|}
\hline Strain name (16S rRNA subgroup) ${ }^{\mathrm{X}}$ & Geographic origin & Host origin & Strain source \\
\hline $\mathrm{EY} 1(\mathrm{~A})^{\mathrm{y}}$ & Ithaca, New York & Ulmus americana & Sinclair \\
\hline $\operatorname{ITEY}(\mathrm{A})^{\mathrm{y}, \mathrm{z}}$ & Northern Italy & U. minor & Lee \\
\hline EY-Pisa ${ }^{z}$ & Pisa, Tuscany, Italy & Ulmus 'Lobel' & Bertaccini \\
\hline EY-Presiola $^{z}$ & Presiola, Emila-Romagna, Italy & Ulmus chenтоиi & Bertaccini \\
\hline EY-NYI & Ithaca, New York & U. americana & Griffiths \& Sinclair \\
\hline EY-NYII & Ithaca, New York & U. americana & Griffiths \& Sinclair \\
\hline EY-WV & Martinsburg, West Virginia & U. rubra & Sinclair \\
\hline EY-Bismarck & Bismarck, North Dakota & U. americana & Walla \\
\hline EY-Fargo & Fargo, North Dakota & U. americana & Walla \\
\hline FD70 $(\mathrm{C})^{\mathrm{y}, \mathrm{z}}$ & France & Vitis vinifera & Boudon-Padieu \\
\hline $\mathrm{RS}(\mathrm{C})^{\mathrm{y}, \mathrm{z}}$ & Northern Italy & Rubus fruticosus & Lee \\
\hline HD1 & Trumansburg, New York & Apocynum cannabinum & Griffiths \& Sinclair \\
\hline$J W B(B)^{y, z}$ & Northern China & Ziziphus jujuba & Lee \\
\hline $\operatorname{CLY}(B)^{y, z}$ & China & Prunus spp. & Lee \\
\hline
\end{tabular}

${ }^{x}$ Subgroups delineated by Lee et al. (10) for characterized strains.

${ }^{\mathrm{y}}$ Samples previously identified, used as standards.

${ }^{\mathrm{z}}$ Nucleic acid sample provided by collector.

Table 2. Arbitrary restriction fragment length polymorphism group designations given to P1/P7 amplimers obtained from 11 strains of phytoplasma group $16 \mathrm{SrV}$ after digestion with 10 restriction enzymes

\begin{tabular}{|c|c|c|c|c|c|c|c|c|c|c|}
\hline \multirow[b]{2}{*}{ Strain } & \multicolumn{10}{|c|}{ Restriction enzyme } \\
\hline & Alu $\mathbf{I}$ & BamHI & $B f a \mathbf{I}$ & HaeIII & HhaI & HpaII & MseI & RsaI & TaqI & ThaI \\
\hline EY1 & I & I & I & I & I & I & I & I & I & I \\
\hline EY-NYII & I & I & I & I & I & I & I & I & I & I \\
\hline ITEY & I & I & I & I & I & I & I & I & I & I \\
\hline EY-Pisa & $\ldots{ }^{y}$ & $\ldots$ & I & $\ldots$ & $\ldots$ & I & $\ldots$ & I & I & $\ldots$ \\
\hline EY-Presiola & $\ldots$ & $\ldots$ & I & $\ldots$ & $\ldots$ & I & $\ldots$ & I & I & $\ldots$ \\
\hline EY-WV & I & $\mathrm{I}^{\mathrm{z}}$ & $\mathrm{I}^{\mathrm{z}}$ & $\mathrm{I}^{\mathrm{z}}$ & $\mathrm{I}^{\mathrm{z}}$ & $\mathrm{I}^{\mathrm{z}}$ & $\mathrm{I}^{\mathrm{z}}$ & II & I & $\mathrm{I}^{\mathrm{z}}$ \\
\hline FD70 & I & I & II & I & I & I & I & I & II & $\mathrm{I}$ \\
\hline HD1 & I & I & II & I & I & I & I & I & II & I \\
\hline RS & I & I & II & I & I & I & I & I & II & I \\
\hline CLY & I & I & I & I & I & II & I & III & III & I \\
\hline JWB & I & I & I & I & I & II & I & III & III & I \\
\hline
\end{tabular}

y ... indicates no data.

${ }^{z}$ Data obtained by sequence analysis of $16 \mathrm{~S}$ rRNA gene. 
data and confirmed for RsaI and TaqI by RFLP analyses, were identical to those of EY1 for all enzymes except RsaI, which had an additional recognition site in the spacer region (Table 2, Figs. 1A and 2). Restriction enzymes BfaI, HpaII, and $R s a$ I were used in analysis of amplimers
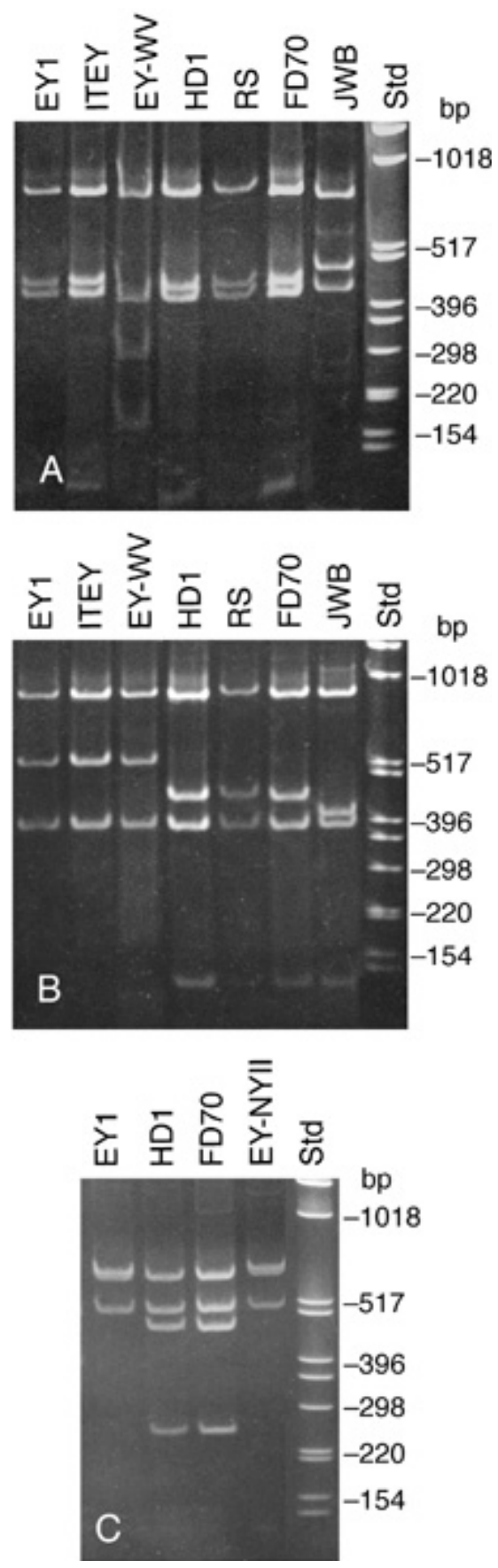

Fig. 1. Restriction fragment length polymorphism profiles of 1.8-kilobase $(\mathrm{kb})$ fragments of rDNA, amplified by polymerase chain reaction (PCR) with primer pair P1/P7, from sources of phytoplasmas in group 16SrV: Catharanthus infected with elm yellows strain EY1, Ulmus sp., Italy (ITEY), U. rubra, West Virginia (EYWV), U. americana, New York (EY-NYII), Apocynum cannabinum (HD1), Rubus fruticosus (RS), Vitis vinifera (FD70), and Ziziphus jujuba (JWB). PCR products were digested with (A) RsaI, (B) TaqI, or (C) BfaI. Std: 1-kb DNA ladder (Gibco-BRL, Grand Island, NY). from strains EY-Pisa and EY-Presiola, because these enzymes had restriction sites that varied among group $16 \mathrm{SrV}$ phytoplasmas (10). The profiles from these digests were identical to those observed with digests of amplimers from EY1 and ITEY (Table 2).

PCR products of the expected size but insufficient for RFLP analysis were obtained with primers P1/P7 and templates from samples EY-NYI, EY-Bismarck, and EY-Fargo. However, with template EYNYI and primers P4/P7, sufficient product (523 bp) was obtained to establish that EYNYI had an extra $R s a$ I site at the same location within the spacer region as observed for strain EY-WV (data not shown). P4/P7 amplimers from strains EY-Bismarck and EY-Fargo, digested with RsaI, had the same profiles as EY1 (data not shown). TaqI profiles were the same for all seven strains obtained from elm trees and resembled that of EY1 (Fig. 1B and data not shown).

Digestion of the P1/P7 amplimer of strain HD1 with the 10 restriction enzymes gave profiles identical to those observed with strains FD70 and RS (Table 2). The $T a q \mathrm{I}$ and $B f a \mathrm{I}$ RFLPs differed from those observed with EY1 (Figs. 1B, C, and 2). Previous work (10) showed that strains FD70 and RS belong to the same subgroup, 16SrV-C. Analysis of sequence data from strains FD70 and RS (GenBank numbers X76560 and Y16395, respectively) and from HD1 obtained in this study (GenBank number AF 122912) confirmed the RFLP findings. FD70 and RS have
99\% similarity, FD70 and HD1 98\% similarity, and RS and HD1 98\% similarity. Therefore, strain HD1 may also be assigned to subgroup $16 \mathrm{SrV}-\mathrm{C}$.

Nucleotide sequences. Alignment of a 1,710-bp sequence of the 16S rRNA gene and $16 \mathrm{~S}-23 \mathrm{~S}$ spacer of strains EY1, EY$\mathrm{WV}$, and HD1 revealed three genotypes corresponding to the RFLP profile groups detected with $B f a \mathrm{I}, R s a \mathrm{I}$, and TaqI. The sequences varied only at three positions, where single base substitutions defined or abolished recognition sites. These sites were a $B f a$ I site (CTAG) at position 11121115 in strain HD1, an RsaI site (GTAC) at position $1550-1553$ in strain EY-WV, and a TaqI site (TCGA) at position 1756-1759 in strain HD1 (Fig. 2). Positions 1550 and 1756 are within variable parts of the spacer; position 1112 is in a conserved region of the $16 \mathrm{~S}$ rRNA gene (13).

FD9f/r amplimers and MseI profiles. FD9f/r (non-ribosomal) amplimers from strains EY1, EY-WV, and EY-NYII were identical when digested with MseI (Fig. 3). Insufficient amplimer was obtained from EY-NYI for analysis. FD9f/r amplimers from strain EY-Pisa, when digested with $M s e I$, gave a profile different from those observed with the North American EY strains. The FD9f/r amplimer from strain HD1, when digested with MseI, gave a unique profile. MseI analysis of amplimers obtained with primer set FD9f/r also differentiated elm-inhabiting strains from others in group $16 \mathrm{SrV}$ (data not shown), as previously demonstrated by Daire et al. (2).
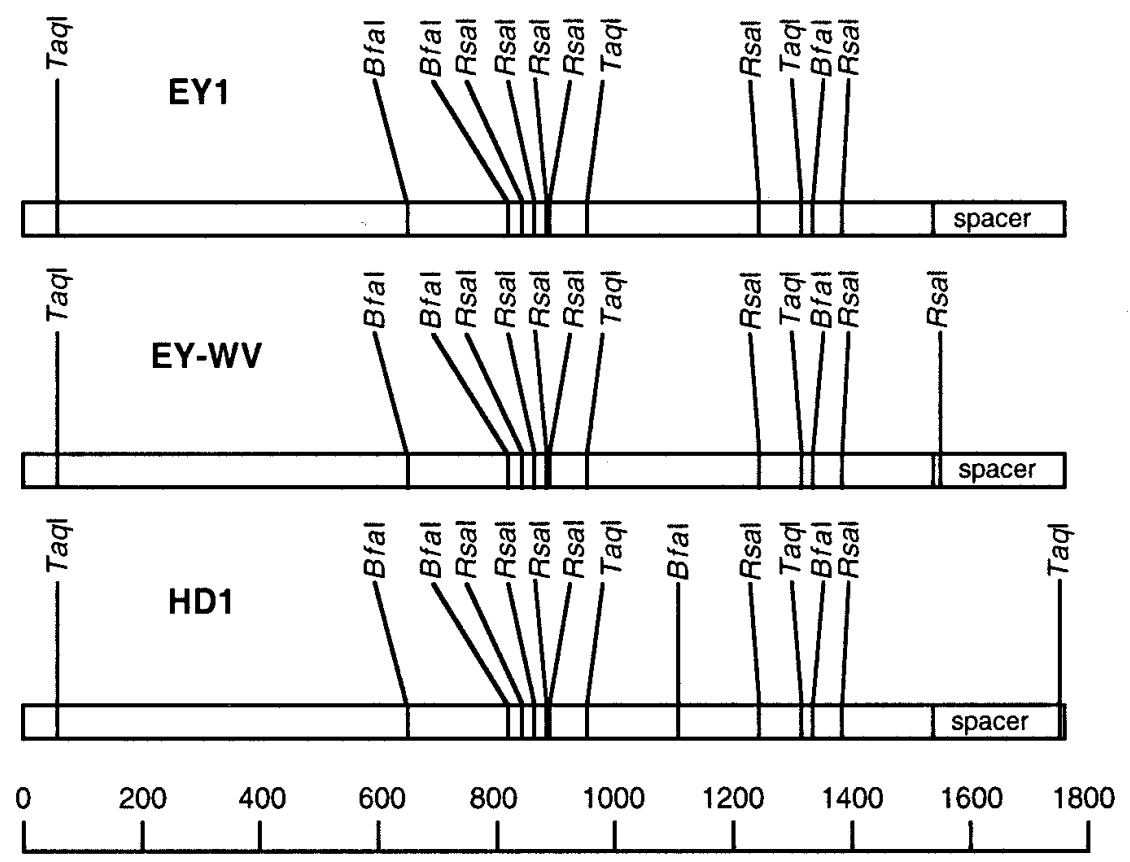

Base pairs

Fig. 2. Restriction maps of restriction fragment length polymorphism profile types obtained by digestion of rDNA of elm yellows (EY) or hemp dogbane (HD) phytoplasma strains with BfaI, RsaI, or TaqI. 


\section{DISCUSSION}

RFLP analysis of $16 \mathrm{~S}$ rDNA plus the $16 \mathrm{~S}-23 \mathrm{~S}$ spacer region of six strains of elminhabiting phytoplasmas from North America revealed variation only at one $R s a \mathrm{I}$ recognition site, located in the $16 \mathrm{~S}-23 \mathrm{~S}$ spacer region. Strains possessing this site were found in New York State and West Virginia. Presence or absence of this site may have no biological significance, because it is in a noncoding region. Moreover, strains EY-NYI and EY-NYII differed at this restriction enzyme site, even though these strains had been detected in adjacent EY-affected trees near Ithaca, New York, during 1997 and 1998, respectively.

Analysis of rDNA revealed no difference between type strain EY1 and Italian phytoplasma strains. However, using the nonribosomal primer pair FD9f/r and restriction enzyme MseI, we found that the EY phytoplasmas inhabiting elm trees in North America are distinct from those inhabiting elm trees in Italy. The Italian EY strain RFLP profiles appeared identical to elm strain ULW from France, as characterized by Daire et al. (2). This suggests that the Italian strains from Pisa and Presiola may be more similar to the French strain ULW than to the North American elm strains.

Phytoplasma-infected A. cannabinum was found on the site of an EY outbreak; therefore, it was important to know if the phytoplasma (HD1) obtained from A. cannabinum was related to the EY agents found in elm trees. Strain HD1 is indeed a member of the EY group sensu lato. How-

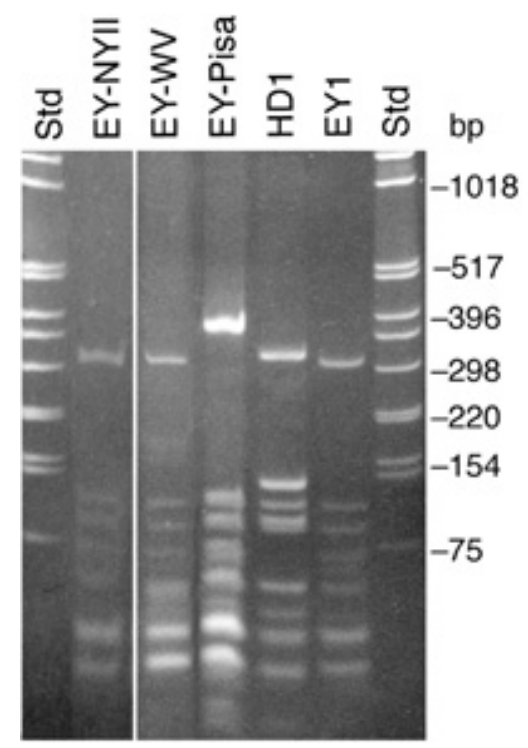

Fig. 3. Restriction fragment length polymorphism profiles, obtained with MseI, of 1.3-kilobase $(\mathrm{kb})$ fragments of non-ribosomal DNA amplified by polymerase chain reaction (PCR) with primer pair FD9f/r from sources of phytoplasmas in group 16SrV: Ulmus americana, New York (EY-NYII); U. rubra, West Virginia (EY-WV), Ulmus 'Lobel' Pisa, Italy (EY-Pisa); Apocynum cannabinum (HD1); and Catharanthus infected with elm yellows strain EY1. Std: 1-kb DNA ladder (Gibco-BRL, Grand Island, NY). ever, it seems more closely related to grapevine- and bramble-inhabiting strains (group 16SrV-C of Lee et al.; 10) than to typical elm-inhabiting strains (group $16 \mathrm{SrV}-\mathrm{A}$ ) and is therefore unlikely to be significant in an EY epidemic. On the basis of the 16S rRNA gene data alone, HD1 would be classified as a member of group $\mathrm{V}-\mathrm{C}$. However, use of the non-ribosomal primer pair FD9f/r and restriction enzyme $M s e I$ revealed that strain HD1 differs not only from the elm strains but also from strains FD70 and RS. Analysis of FD9f/r amplimers with restriction enzyme MseI had previously been valuable for differentiating among grapevine phytoplasmas belonging to the EY group and between two strains of EY (2).

Lee et al. (9) and Bertaccini et al. (1) reported heterogeneity of phytoplasmas of the EY group in elms, whereas Mäurer et al. (18) and Marcone et al. (15) reported that elm-inhabiting phytoplasmas of this group seemed to be homogeneous. Results of analyses of ribosomal and non-ribosomal DNA support the concept that elminhabiting phytoplasmas compose a taxonomically discrete but non-uniform subgroup (16SrV-A). Phenotypic variation in this subgroup should be assessed.

\section{ACKNOWLEDGMENTS}

We thank J. A. Walla (Plant Pathology Department, North Dakota State University, Fargo 58105) for providing elm samples from Bismarck and Fargo, North Dakota; and anonymous reviewers for helpful comments.

\section{LITERATURE CITED}

1. Bertaccini, A., Vibio, M., Gennari, F., Guerrini, S., Benni, A., and Lee, I.-M. 1995. Detection of mycoplasmalike organisms (phytoplasmas) in Rubus by nested polymerase chain reaction (PCR). Acta Hortic. 385:126-131

2. Daire, X., Clair, D., Reinert, W., and BoudonPadieu, E. 1997. Detection and differentiation of grapevine yellows phytoplasmas belonging to the elm yellows group and to the stolbur subgroup by PCR amplification of non-ribosomal DNA. Eur. J. Plant Pathol. 103:507-514.

3. Dellaporta, S. L., Wood, J., and Hicks, J. B. 1983. A plant DNA minipreparation: Version II. Plant Mol. Biol. Rep. 1:19-21.

4. Deng, S., and Hiruki, C. 1991. Amplification of 16S rRNA genes from culturable and nonculturable Mollicutes. J. Microbiol. Methods 14:53-61.

5. DNASTAR, Inc. 1997. LASERGENE Biocomputing Software for the Macintosh. DNASTAR, Inc. Madison, WI.

6. Griffiths, H. M., Sinclair, W. A., Gundersen, D. E., Lee, I.-M., and Davis, R. E. 1994. Characterization of mycoplasmalike organisms detected in plants in the vicinity of natural outbreaks of ash yellows and elm yellows in North America. IOM Lett. 3:259-260.

7. Griffiths, H. M., Sinclair, W. A., Lee, I.-M., Boudon-Padieu, E., Daire, X., and Smart, C. 1997. Implications of differences between elm inhabiting phytoplasmas and others in 16S rRNA group V. (Abstr.) Eur. J. For. Pathol. 28:75-83.

8. Lee, I.-M., Bertaccini, A., Vibio, M., Gundersen, D. E., Davis, R. E., Mittempergher, L., Conti, M., and Gennari, F. 1995. Detection and characterization of phytoplasmas associated with disease in Ulmus and
Rubus in northern and central Italy. Phytopathol. Mediterr. 34:174-183.

9. Lee, I.-M., Davis, R. E., Sinclair, W. A., Dewitt, N. D., and Conti, M. 1993. Genetic relatedness of mycoplasmalike organisms detected in Ulmus spp. in the United States and Italy by means of DNA probes and polymerase chain reactions. Phytopathology 83:829-833.

10. Lee, I.-M., Gundersen-Rindal, D. E., Davis, R. E., and Bartoszyk, I. M. 1998. Revised classification scheme of phytoplasmas based on RFLP analyses of 16S rRNA and ribosomal protein gene sequences. Int. J. Syst. Bacteriol. 48:1153-1169.

11. Lee, I.-M., Hammond, R. W., Davis, R. E., and Gundersen, D. E. 1993. Universal amplification and analysis of pathogen 16S rDNA for classification and identification of mycoplasmalike organisms. Phytopathology 83:834-842.

12. Lee, I.-M., Zhu, S. F., Gundersen, D. E., Zhang, C., and Hadidi, A. 1995. Detection and identification of a new phytoplasma associated with cherry lethal yellows in China. (Abstr.) Phytopathology 85:1179.

13. Lim, P. O., and Sears, B. B. 1989. 16S rRNA sequence indicates that plant-pathogenic mycoplasmalike organisms are evolutionarily distinct from animal mycoplasmas. J. Bacteriol. 171:5901-5906.

14. Marcone, C., Raggozino, A., Firrao, G., and Locci, R. 1994. Detection of elm witches'broom agent in Basilicata, southern Italy. Phytopathol. Mediterr. 33:194-199.

15. Marcone, C., Ragozzino, A., and Seemüller, E. 1997. Identification and characterization of the phytoplasma associated with elm yellows in southern Italy and its relatedness to other phytoplasmas of the elm yellows group. Eur. J. For. Pathol. 27:2745-2754

16. Martini, M., Vibio, M., Sfalanga, A., and Bertaccini, A. 1998. Molecular and ecological diversity of phytoplasmas belonging to the elm yellows group in Italy towards their tentative epidemiology. Abstr. D.22. Page 130 in: 12th Int. Organ. Mycoplasmol. Conf. Sydney, Australia.

17. Matteoni, J. A., and Sinclair, W. A. 1989. A note on the presence of elm yellows in the Niagara Peninsula. Phytoprotection 70:137-140.

18. Mäurer, R., Seemüller, E., and Sinclair, W. A. 1993. Genetic relatedness of mycoplasma-like organisms affecting elm, alder, and ash in Europe and North America. Phytopathology 83:971-976.

19. Sambrook, J., Fritsch, E. F., and Maniatis, T. 1989. Molecular Cloning, a Laboratory Manual, 2nd ed. Cold Spring Harbor Laboratory, Cold Spring Harbor, NY.

20. Schneider, B., Seemüller, E., Smart, C. D. and Kirkpatrick, B. C. 1995. Phylogenetic classification of plant pathogenic mycoplasma-like organisms or phytoplasmas. Pages 369-380 in: Molecular and Diagnostic Procedures in Mycoplasmology, Vol. 1. S Razin and J. G. Tully, eds. Academic Press, San Diego, CA.

21. Seemüller, E. 1976. Investigations to demonstrate mycoplasmalike organisms in diseased plants by fluorescence microscopy. Acta Hortic. 67:109-112.

22. Seemüller, E., Marcone, C., Lauer, U., Ragozzino, A., and Göschl, M. 1998. Current status of molecular classification of the phytoplasmas. J. Plant Pathol. 80:3-26.

23. Sinclair, W. A. 1981. Elm yellows. Pages 2531 in: Compendium of Elm Diseases. R. J. Stipes and R. J. Campana eds. American Phytopathological Society, St Paul, MN.

24. Sinclair, W. A., Iuli, R. J., Dyer, A. T., and Larsen, A. O. 1989. Sampling and histological procedures for diagnosis of ash yellows. Plant Dis. 73:432-435. 
ERRATUM / Volume 83, Number 12, 1999

In the article "Phytoplasmas Associated with Elm Yellows: Molecular Variability and Differentiation from Related Organisms" by H. M. Griffiths, W. A. Sinclair, E. BoudonPadieu, X. Daire, I.-M. Lee, A. Sfalanga, and A. Bertaccini, on pages 1101 to 1104, Figure 2 should appear as follows:

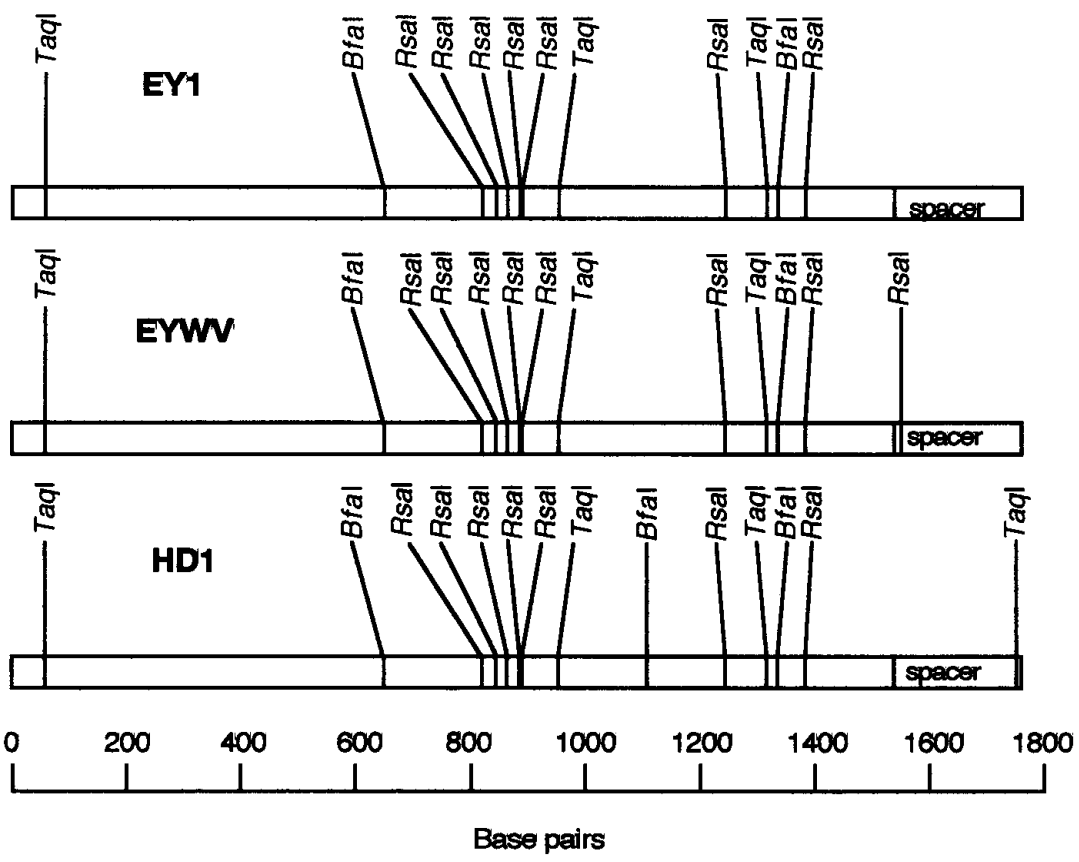

Fig. 2. Restriction maps of restriction fragment length polymorphism profile types obtained by digestion of rDNA of elm yellows (EY) or hemp dogbane (HD) phytoplasma strains with BfaI, RsaI, or TaqI. 